\title{
EFEK MEKANISME GOOD CORPORATE GOVERNANCE DAN KINERJA KEUANGAN TERHADAP NILAI PERUSAHAAN
}

\author{
Iin Ariska ${ }^{1}$, Mohamad Nur Utomo ${ }^{2}$ \\ mohnurutomo@gmail.com
}

Fakultas Ekonomi, Universitas Borneo Tarakan

\begin{abstract}
ABSTRAK
Penelitian ini bertujuan untuk menguji efek kepemilikan institusional, dewan komisaris independen, profitabilitas dan likuiditas terhadap nilai perusahaan. Perusahaan sektor manufaktur barang dan konsumsi yang terdaftar di Bursa efek Indonesia menjadi sampel dalam penelitian ini dengan periode 2015-2019. Analisis data menggunakan metode statistik. Hasil penelitian menunjukkan Kepemilikan Institusional dan Profitabilitas berpengaruh positif dan signifikan terhadap nilai perusahaan. Sementara Dewan komisaris Independen berpengaruh negatif dan tidak signifikan terhadap nilai perusahaan, Likuditas berpengaruh positif dan tidak signifikan. Penelitian ini memberikan implikasi bahwa peningkatan monitoring dari pemegang saham institusional dan peningkatan profitabilitas sebagai cara yang efektif untuk meningkatkan nilai perusahaan. Selain itu perusahaan harus tetap meningkatkan peran pengawasan dewan komisaris independen dan menjaga tingkat likuiditas agar memiliki keunggulan dalam jangka panjang.
\end{abstract}

Kata kunci : Kepemilikan institusional, dewan komisaris independen, profitabilitas, likuiditas, nilai perusahaan

\begin{abstract}
ABSTRACK
This study aims to examine the effects of institutional ownership, independent board of commissioners, profitability and liquidity on firm value. Goods and consumer manufacturing companies listed on the Indonesia Stock Exchange were sampled in this study with the period 2015 to 2019. Data analysis used statistical methods. The results showed that Institutional Ownership and Profitability had a positive and significant effect on firm value. Meanwhile, the independent board of commissioners has a negative and insignificant effect on firm value, liquidity has a positive and insignificant effect. This study implies that increased monitoring of institutional shareholders and increased performance is an effective way to increase firm value. In addition, the company must continue to improve the supervisory role of the independent board of commissioners and maintain the level of liquidity in order to have a long-term advantage.
\end{abstract}

Keywords: Institutional ownership, independent board of commissioners, profitability, liquidity, firm value 


\section{PENDAHULUAN}

Nilai perusahaan merupakan gambaran keberhasilan perusahaan yang dikaitkan dengan nilai harga saham dari para investor. Dengan harga saham yang meningkat maka nilai perusahaan mengalami peningkatan. Memaksimalkan nilai perusahaan merupakan tujuan utama perusahaaan (Anggraini, 2013). Nilai perusahaan menjadi hal penting bagi investor, untuk menilai perusahaan secara keseluruhan yang merupakan indikator bagi pasar (Wijaya, 2010). Dalam upaya untuk meningkatkan nilai perusahaan pasti akan terjadinya konflik kepentingan atau biasa yang disebut komflik agensi.

Pihak manajer dengan kekuasaan yang dimilikinya mampu bertindak untuk lebih mementingkan kepentingan pribadinya dan mengorbankan kepentingan pemegang saham (Trisnantari, 2008) Kepentingan perbedaan yang terjadi antara agen dan prinsipal inilah yang melatarbelakangi terjadinya Good Corporate Governance. Salah satu upaya meningkatkan nilai perusahaan ialah dengan struktur kepemilikan perusahaan yaitu Kepemilikan Instituisonal, yang berperan memonitoring agen perusahaan. Selain itu Perusahaan dapat diawasi juga oleh dewan komisaris indepeden. Pengawasan dari dewan komisaris independen mampu mengurangi masalah agensi dan mengutamakan kemakmuran prinsipal (Tertuis \& Christiawan, 2015). Kinerja keuangan dapat dikur dengan menggunakan beberapa rasio keuangan namun peneliti menggunakan likuiditas (CR) dan profitabilitas (ROA) sebagai variable kinerja keuangan (Tertuis \& Christiawan, 2015)

Menurut (Prasinta, 2012), apabila profitabilitas perusahaan meningkat maka nilai perusahaan juga semakin tinggi yang dilihat dengan terjadinya kenaikan saham. Likuiditas menjadi perhatian serius pada perusahaan sehingga likuiditas memiliki peran yang sangat penting karena dia mampu memainkan peranan dalam kesuksesan perusahaan (Putra \& Lestari, 2016). Pada Perusahaan likuditas yang baik akan dianggap oleh investor memiliki kinerja yang baik (Putra \& Lestari, 2016). Salah satu pengukuran nilai perusahaan yang digunakan peneliti adalah Tobins'Q. Dengan Tobins'Q kita dapat mengukur kinerja perusahaan, khususnya tentang nilai perusahaan dalam mengelola aktiva perusahaan (Sarafina \& Muhammad Saifi, 2016).

Fenomena kondisi melemahnya sistem tata kelola perusahaan (Good Corporate Governance) dan perlindungan bagi investor sehingga mendorong para pemilik perusahaan untuk meningkatkan pengawasannya. Namun pada faktanya ditemukan 
beberapa perusahaan sektor manufaktur di Bursa Efek iIndonesia memiliki kinerja keuangan (diukur dengan ROA) yang tinggi namun tidak selalu diikuti dengan nilai perusahaan (diukur dengan Tobins'Q) yang tinggi, disajikan pada Gambar 1.

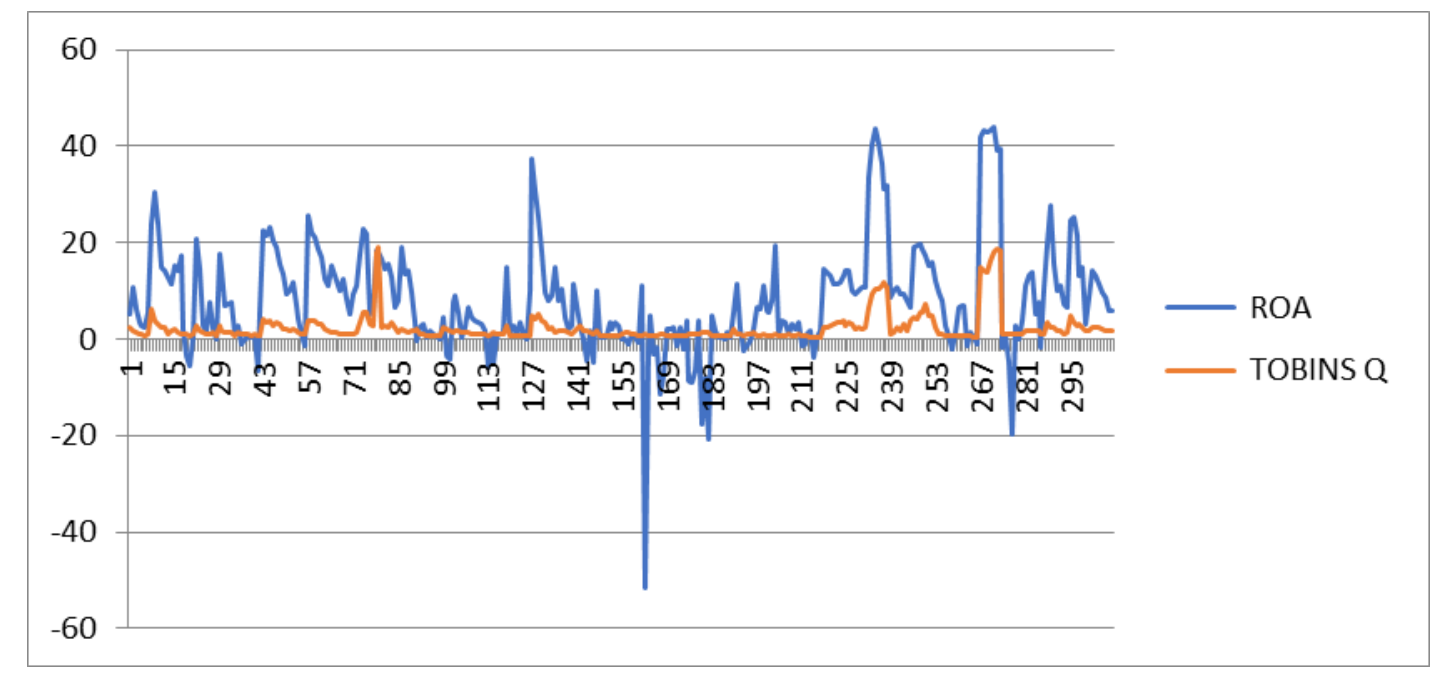

Gambar 1 .

Grafik ROA dan Tobins'Q perusahaan Sektor Manufaktur 2015-2019 di BEI

Berdasarkan Gambar 1 dapat dijelaskan bahwa nilai ROA yang tinggi tidak selalu diikuti dengan nilai Tobins' $Q$ yang tinggi juga tetapi terdapat perusahaan yang memiliki ROA yang tinggi di ikuti dengan nilai Tobins $Q$ yang rendah atau sebaliknya. Dari fenomena yang ditunjukkan pada Gambar 1 tersebut dapat dimaknai bahwa nilai perusahaan tidak hanya selalu dipengaruhi oleh kinerja keuangan (ROA). Sehingga menimbulkan pertanyaan faktor-faktor apa saja yang menyebabkan naik atau turunnya nilai perusahaan. Penelitian ini ingin menguji faktor-faktor lainnya yang mungkin mempengaruhi nilai perusahaan. Berdasarkan uraian sebelumnya bahwa nilai perusahaan dapat dipengaruhi oleh pengawasan yang dilakukan oleh komisaris independen, dan kepemilikan institusional dan kinerja keuangan. Penelitian ini mencoba menganalisis pengaruh mekanisme corporate governance yang diwakili oleh dewan komisaris independen dan kepemilikan institusional serta kinerja keuangan, yang diwakili oleh rasio likuiditas dan profitabilitas. 


\section{LANDASAN TEORI DAN PENGEMBANGAN HIPOTESIS}

\section{Teori Agensi}

Teori agensi menjelaskan adanya kontrak antara agen (manager) atau prinsipal (pemegang saham) dalam upaya untuk meningkatkan nilai perusahaan pasti akan muncul konflik kepentingan antara agen dan prinsipal (Michael \& H Meckling William, 1976). Teori agensi berkaitan dengan konflik kepentingan terjadi adanya perbedaan dari masingmasing pihak berdasarkan kepentingan terhadap perusahaan. Sebagai manajer, dia harus bertanggung jawab untuk memaksimalkan keuntungan para pemiliknya (principal), namun manajer juga menginginkan untuk mendapatkan kompensasi sesuai dengan kontrak. Sehingga terjadilah perbedaan kepentingan antara dua pihak yang berbeda dimana masingmasingnya berupaya untuk mendapatkan atau mempertahankan kemakmuran yang dikehendaki (Laila, 2011). Teori agensi melatar belakangi peran mekanisme good corporte governance seperti kepemilikan institusional dan dewan komisaris independen dalam mengawasi dan mendorong manajer meningkatkan nilai perusahaan.

\section{Teori Signaling}

Teori Sinyal atau signaling teory adalah salah satu teori yang berkaitan dengan manajemen keuangan, teori signaling dapat diartikan sebagai isyarat yang memberikan suatu sinyal yang akan berusahaan memberikan sejumlah informasi relevan yang dapat dimanfaatkan oleh pihak penerima (Spence, 1973). Perusahaan secara kualitas memang lebih bagus dituntut untuk kreatif dan berani menggunakan sinyal-sinyal yang dapat menunjukkan bahwa diri mereka yang lebih baik yaitu salah satunya dengan metode yang dapat dilakukan manajer adalah teori sinyal. Sinyal yang diberikan berupa kekuatan informasi untuk dapat merubah penilaian bahwa perusahaan tersebut lebih baik dan tidak dapat dibandingkan daripada perusahaan lain dan informasi lainnya (Spence, 1973). Teori signal mendasari bahwa kinerja keuangan yang tinggi menjadi signal yang baik bagi perusahaan dan memperoleh valuasi yang tinggi dari para investor.

\section{Kepemilikan Institusional dan Nilai Perusahaan.}

Kepemilikan Institusional mempunyai peranan penting untuk meminimalisirkan konflik keagenan yang terjadi antara prinsipal dengan agen (Azzahra \& Yuliandari, 2014). Kepemilikan institusional berguna untuk mengawasi secara profesional perkembangan investasi sehingga tingkat pengendalian manajemen sangat tinggi serta potensi kecurangan 
dapat ditekan dan dapat menghalangi perilaku opotunistic manajer. Kepemilikan institusional pada perusahaan akan mendorong peningkatan pengawasan yang lebih optimal pada manajer dalam upaya meningkatkan kinerja. Semakin tinggi kepemilikan institusional semakin efisien pula pemanfaatan aktiva perusahaan, maka dengan pengawasan yang efektif oleh pemegang saham institusional terhadap perusahaan diharapkan mampu mencegah perilaku pemborosan yang dilakukan oleh manajemen yang dapat merugikan pemegang saham (L. C. Dewi \& Nugrahanti, 2014).

Damayanti \& Suartana, (2014) dalam studinya meneliti tentang pengaruh kepemilikan institusional dan kepemilikan manajerial pada nilai perusahaan menemukan bahwa kepemilikan institusional berpengaruh positif signifikan pada nilai perusahaan. Sementara Sienatra et al., (2015) melakukan penelitian yang serupa tentang struktur kepemilikan perusahaan sebagai determinasi bagi nilai perusahaan. Penelitian ini menggunakan analisis jalur dengan mengambil sampel perusahaan manufaktur di Bursa Efek Indonesia. Kepemilikan institusional rata-rata memiliki nilai sebesar 70,12\% dari total kepemilikan saham diperusahaan. Hasil penelitian menunjukkan bahwa kepemilikan instituisonal sebagai salah satu penentu nilai perusahaan.

Selanjutnya penelitian Julianti, (2015) tentang pengaruh corporate governance terhadap nilai perusahaan pada perusahaan manufaktur di Bursa Efek Indoensia dengan profitabilitas sebagail variabel Intervening. Hasil penelitian mendukung penelitianpenelitian sebelumnya yang menyatakan bahwa kepemilikan institusional sebagai salah satu variabel corporate governance berdampak positif terhadap nilai perusahaan. Dengan demikian hal ini menunjukkan bahwa kepemilikan institusional mampu menjadi mekanisme good corporate governance yang dapat mendorong meningkatkan nilai perusahaan.

\section{Dewan Komisaris Independen dan Nilai perusahaan.}

Peran dewan komisaris independen dalam perusahaan sangat bermanfaat ketika mendorong suatu pengambilan keputusan yang memberikan perlindungan bagi pemegang saham minoritas dan pihak-pihak lain yang terkait dalam perusahaan. Keberadaan komisaris independen diharapkan mampu untuk meningkatkan efektifitas pengawasan dan mengupayakan peningkatan kualitas dari kinerja keuangan. Sehingga kinerja keuangan semakin baik dan investor semakin percaya untuk menanamkan modalnya pada perusahaan. Komisaris Independen diharapkan dapat bertanggung jawab membawa 
penilaian independen untuk menanggung pada masalah strategi, kinerja dan sumber daya termasuk standar perilaku (L. C. Dewi \& Nugrahanti, 2014).

Tambunan et al., (2017) dalam studi empirisnya menemukan bahwa mekanisme corporate governance yang diwakili oleh dewan komisaris independen, kepemilikan institusional dan komite audit memiliki pengaruh secara simultan terhadap nilai perusahaan. Siallagan \& Machfoedz, (2006) meneliti tentang hubungan mekanismene corporate governance, kualitas Laba dan nilai perusahaan. Analisis data menggunakan metode regresi berganda dengan sampel semua perusahaan yang terdaftar disektor manufaktur. Hasil penelitian menemukan bahwa mekanisme corporate governance mempengaruhi kualitas laba, kualitas laba berpengaruh positif terhadap nilai perusahaan. Selain itu mekanisme corporate governance yang terdiri dari dewan komisaris dan komite audit secara positif berpengaruh terhadap nilai perusahaan. Penelitian lainnya yang mendukung studi sebelum dilakukan oleh Utomo et al., (2018) dengan menggunakan teknik analisis Structural Equation Modeling (SEM) membuktikan bahwa peran pengewasan dewan komisaris independen berdampak positif terhadap nilai perusahaan.

\section{Profitabilitas dan Nilai Perusahaan}

Rasio profitabilitas merupakan kemampuan perusahaan dalam menghasilkan laba dengan modal yang ditanamkan didalam perusahaan. Profitabilitas merupakan kemampuan perusahaan dalam memperoleh keuntungan dari usahanya semakin baik pertumbuhan profitabilitas perusahaan berarti prospek perusahaan di masa depan akan semakin baik dimata investor (Sudiani \& Darmayanti, 2016).

Hasil studi Alfredo Mahendra Dj et al., (2012) yang meneliti tentang pengaruh kinerja keuangan terhadap nilai perusahaan pada perusahaan manufaktur di Bursa Efek Indonesia. Menggunakan analisis statistik yaitu Uji regresi, hasil dari penelitian ini menunjukkan bahwa profitabilitas berpengaruh positif signifikan terhadap nilai perusahaan.

Nurhayati, (2013) meneliti tentang pengaruh likuiditas, profitabilitas, dan ukuran perusahaan terhadap nilai perusahaan pada sekor non jasa. Analisis data menggunakan analisi Jalur. Hasil penelitian menyatakan bahwas ukuran perusahaan berdampak negatif dan signifikan terhadap kebijakan dividen. Profitabilitas perusahaan memiliki dampak positif dan signifikan pada kebijakan dividen. Likuiditas perusahaan memiliki efek negatif dan signifikan pada kebijakan dividen. Likuiditas perushaan memiliki dampak positif dan 
signifikan pada nilai perusahaan. Profitabilitas berhubungan positif dan signifikan pada nilai perusahaan. Kebijakan dividen tidak berdampak signifikan pada nilai perusahaan.

Dewi et al., (2014) dalam penelitianya tentang pengaruh struktur modal, pertumbuhan perusahaan dan profitabilitas terhadap nilai perusahaan pada Perusahaan LQ45 di Bursa Efek Indonesia. Hasil penelitian menunjukkan bahwasanya secara parsial struktur modal, pertumbuhan perusahaan, serta profitablitas masing-masing berpengaruh positif dan signifikan terhadap nilai perusahaan.

\section{Likuiditas dan Nilai Perusahaan}

Likuiditas merupakan kemampuan perusahaan untuk membayar kewajiban jangka pendeknya yang akan direspon positif oleh pasar. Perusahaan dengan tingkat likuiditas yang tinggi akan berdampak pada kepercayaan pasar pada perusahaan. Jika perusahaan dapat menjaga tingkat likuiditasnya menjadi signal bagi investor bahwa perusahaan tersebut telah memiliki kinerja yang baik (Sudiani \& Darmayanti, 2016).

Beberapa studi empiris menunjukkan bahwa likuiditas berdampak pada nilai perusahaan. Seperti penelitian Nurhayati, (2013) yang menemukan bahwa likuiditas perusahaan memiliki dampak positif dan signifikan terhadap nilai perusahaan. Rompas, (2016) menunjukkan bahwa likuditas yang diukur dengan menggunakan Current ratio, Quick ratio menjadi salah satu penentu tingginya nilai perusahaan. Selain itu Anzlina \& Rustam, (2013) dari hasil studinya menyatakan bahwa perusahaan harus memperhatikan tingkat current ratio untuk meningkatkan kepercayaan investor terhadap perusahaan. Keputusan investor menanamkan investasinya pada perusahaan akan memperioritaskan pada perusahaan yang mepunyai current ratio yang lebih tinggi dibandingkan dengan perusahaan yang memiliki current ratio yang rendah.

\section{Rumusan Hipotesis}

Maka berdasarkan uraian diatas dapat diajukan hipotesis dalam penelitian ini sebagai berikut :

$\mathrm{H}_{1}$ : kepemilikan institusional berpengaruh positif terhadap nilai perusahaan

$\mathrm{H}_{2}$ : Dewan Komisaris Independen berpengaruh positif terhadap nilai perusahaan

$\mathrm{H}_{3}$ : Profitabilitas berpengaruh positif terhadap nilai perusahaan. 
$\mathrm{H}_{4}$ : Likuiditas berpengharuh positif terhadap nilai perusahaan.

\section{METODE PENELITIAN}

\section{Data sampel Penelitian}

Sampel dalam penelitian ini adalah perusahaan sektor manufaktur barang dan konsumsi di Bursa Efek Indonesia. Periode penelitian dari tahun 2015 sampai dengan tahun 2019. Teknik pengambilan sampel menggunakan purposive sampling (sampel bertujuan). Kriteria yang digunakan dalam pemilihan sampel adalah sebagai berikut: (1) Perusahaan Manufaktur sektor barang dan konsumsi yang terdaftar di Bursa Efek Indonesia selama tahun 2015-2019 (2) Perusahaan yang melaporkan laporan keuangan dalam satuan uang rupiah. (3) Perusahaan yang tidak pindah sektor selama periode pengamatan. (4) Perusahaan memiliki data lengkap mengenai kepemilikan institusional, dewan komisaris independen, profitabilitas, likuiditas. Sumber data yang digunakan dalam penelitian ini adalah data sekunder dari laporan keuangan dan laporan tahunan perusahaan yang terdaftar di Bursa Efek Indonesia yang diperoleh dari www.idx.com. Teknik pengumpulan data menggunakan data dokumentasi.. Berdasarkan kriteria tersebut diperoleh 36 sampel perusahaan terdiri dari 14 perusahaan sub sektor makanan dan minuman, 4 perusahaan sub sektor rokok, 10 perusahaan sub sektor farmasi, 7 perusahaan sub sektor kosmetik, dan 2 perusahaan sub sektor peralatan rumah tangga, dengan periode penelitian 5 tahun. Sehingga total data yang diperoleh sebanyak 180 (36x5 tahun). Namun untuk keperluan normalitas data sebanyak 30 data terindikasi outlier sehingga dibuang dan menyisakan data yang dianalisis sebanyak 150 .

\section{Pengukuran variabel}

Variabel dependen dalam penelitian ini adalah nilai perusahaan. Nilai perusahaan juga dikatakan nilai pasar adalah nilai perusahaan mampu memberikan kesejahteraan bagi pemegang saham apabila harga saham meningkat (Kusumadilaga, 2010). Pengukuran nilai perusahaan dalam penelitian ini menggunakan Tobin's Q (Q) mengacu pada penelitian Utomo, (2018) yang dapat dirumuskan sebagai berikut :

$$
\text { Tobins }^{\prime} Q=\frac{(\text { Harga pasar saham X Total lembar saham })+\text { Total Utang }}{\text { Total assets }}
$$


Varaibel independen dalam penelitian ini meliputi kepemilikan institusional, dewan komisaris independen, profitabilitas dan likuiditas. Kepemilikan institusional mempunyai fungsi dalam meminimalisasi keagenan konflik yang terjadi diantara prinsipal dengan manajer (Azzahra \& Yuliandari, 2014). Kepemilikan Institusional (KI) dalam penelitian ini dapat diukur dengan mengacu pada penelitian Azzahra \& Yuliandari, (2014) yaitu dengan menghitung persentasi dari jumlah saham kepemilikan institusional berbanding dengan jumlah saham yang beredar.

Dewan komisaris independen bertugas untuk menjaga pada saat pengambilan keputusan dalam upaya perlindungan terhadap pemegang saham minoritas serta pihak pihak yang berkaitan dengan perusahaan. Dewan komisaris independen (DKI) dalam penelitian ini dapat diukur dengan mengacu pada penelitian Sarafina \& Muhammad Saifi, ( 2016), yang dihitung dengan persentasi jumlah dewan komisaris independen dengan jumlah total seluruh dewan komisaris.

Profitabilitas merupakan tingkat keuntungan bersih yang mampu dicapai oleh perusahaan ketika menjalankan operasinya (Wulandari, 2013). Melalui rasio keuangan dapat menjadi indikator untuk mengetahui nilai perusahaan. Profitabilitas dalam penelitian ini diukur dengan rasio Return On asset (ROA) yang mengacu pada penelitian Wulandari, (2013) dapat dituliskan secara rinci sebagai berikut:

$$
R O A=\frac{\text { Earning After Tax }}{\text { Total assets }}
$$

Likuiditas ialah kemampuan perusahaan dalam membayar kewajiban jangka pendeknya yang telah jatuh tempo (Wulandari, 2013). Pengukuran likuiditas dengan menggunakan rasio current ratio (CR) dengan mengacu pada penelitian Wulandari, (2013), dapat dituliskan secara rinci sebagai berikut:

$$
\text { CR }=\frac{\text { Current Assets }}{\text { Current Liabilities }}
$$

\section{Metode analisis}

Penelitian ini menggunakan metode statistik dengan menggunakan analisis regresi berganda dengan aplikasi SPSS. Berdasarkan model penelitian maka dapat dibuat persamaan regresi sebagai berikut: 


$$
Q=\alpha_{1}+\beta_{1} K I+\beta_{2} D K I+\beta_{3} R O A+\beta_{4} C R+\mathrm{e}_{1}
$$

Dimana $\mathrm{Q}=$ Tobins $\mathrm{Q}, \mathrm{KI}=$ Kepemilikan Institusional, DKI $=$ Dewan Komisaris Independen, $\mathrm{ROA}=$ Return On Asset dan $\mathrm{CR}=$ Current Ratio.

\section{HASIL PENELITIAN DAN PEMBAHASAN}

\section{Deskriptif statistik}

Hasil uji statistik deskriptif variabel dalam penelitian ini meliputi nilai data observasi sampel $(\mathrm{N})$, minimum, maximum, mean dan standar deviasi disajikan pada Tabel 1.

\section{Tabel 1.Deskriptif Statistik}

\begin{tabular}{lccccc}
\hline & $\mathrm{N}$ & Minimum & Maximum & Mean & $\begin{array}{c}\text { Std. } \\
\text { Deviation }\end{array}$ \\
\hline $\begin{array}{l}\text { Kepemilikan } \\
\text { Institusional }\end{array}$ & 150 & 0,01 & 1,00 & 0,6874 & 0,22759 \\
$\begin{array}{l}\text { Dewan Komisaris } \\
\text { Independen }\end{array}$ & 150 & 0,25 & 1,00 & 0,4107 & 0,10919 \\
Profitabilitas & 150 & $-0,17$ & 0,23 & 0,0621 & 0,07108 \\
Likuiditas & 150 & 0,02 & 9,28 & 2,8405 & 1,83518 \\
Nilai Perusahaan & 150 & 0,16 & 4,99 & 1,7451 & 1,16559 \\
\hline
\end{tabular}

Sumber : Data Bursa Efek Indonesia diolah (2020)

Berdasarkan Tabel 1 dapat dilihat Kepemilikan Institusional dengan nilai mean 0,6874 artinya rata-rata kepemilikan institusional perusahaan sektor manufaktur di bidang barang dan konsumsi tergolong sebagai kepemilikan saham yang besar yakni diatas $50 \%$. Dewan komisaris independen dengan nilai rata-rata 0,4107 atau 41,07\%, hal ini menunjukkan perusahaan dalam sampel penelitian ini telah memenuhi regulasi jumlah persentase minimal dewan komisaris independen di indonesia yakni minimal $30 \%$ dari total seluruh dewan komisaris. Variabel profitabilitas (ROA) memiliki nilai mean sebesar 0,0621 atau $6,21 \%$, artinya rata-rata perusahaan memiliki kinerja atau profitabilitas yang positif atau dalam kondisi tidak merugi. Sementara dari variabel likuiditas (current ratio) memiliki nilai mean sebesar 2,84, hal ini menunjukkan rata-rata perusahaan memiliki tingkat likuiditas yang baik yakni diatas angka 1 (satu) yang menandakan nilai asset lancar lebih besar dari utang lancar.

\section{Uji Asumsi Klasik}


Uji asumsi klasik penelitian ini meliputi uji normalitas, uji multikolinieritas dan uji heteroskedastisitas.

\section{Uji Normalitas}

Uji normalitas data dalam penelitian ini menggunakan kolmogorov-smirnov test yang disajikan pada Tabel 2.

Tabel 2. One-Sampel Kolmogorov-Smirnov Test

\begin{tabular}{llc}
\hline & & Unstandardized Residual \\
\hline $\mathrm{N}$ & & 150 \\
Normal Parameters & a.b & 0 \\
& Mean & 0,83674578 \\
& Std. & 0,063 \\
Most Extreme & Deviation & 0,063 \\
Differences & Absolute & $-0,041$ \\
& Positive & 0,063 \\
Test Statistic & Negative & $0,200^{\mathrm{c,d}}$ \\
Asymp. Sig. (2-tailed) & &
\end{tabular}

Berdasarkan Tabel 2 didapatkan nilai asymp.sig (2-tailed) sebesar 0,2 yang lebih besar dari nilai yang dipersyaratkan $(>0,05)$, sehingga dapat dinyatakan model regresi telah terdistribusi normal.

\section{Uji Multikolinieritas}

Hasil uji multikolinieritas disajikan Tabel 3, dimana didapat perhitungan nilai tolerance kurang dari 0,10 yang berarti tidak ada korelasi antar variabel independen. Hasil perhitungan nilai VIF menunjukkan tidak ada satu variabel independen yang memiliki nilai VIF lebih dari 10, jadi dapat disimpulkan bahwa tidak ada multikolonieritas antar variabel independen dalam model regresi.

Tabel 3.Uji Multikolinieritas

\begin{tabular}{lcc}
\hline \multicolumn{1}{c}{ Model } & Collinearity Statistics Tolerance & VIF \\
\hline (Constanta) & & \\
Kepemilikan Institusional & 0,937 & 1,067 \\
Dewan Komisaris & 0,928 & 1,078 \\
Independen & 0,851 & 1,175 \\
Profitabilitas & 0,843 & 1,186 \\
Likuiditas &
\end{tabular}

Sumber : Data Bursa Efek Indonesia diolah (2020) 


\section{Uji Heteroskedastisitas}

Uji heteroskedastisitas menggunakan gambar scatterplot yang disajikan pada Gambar 2.

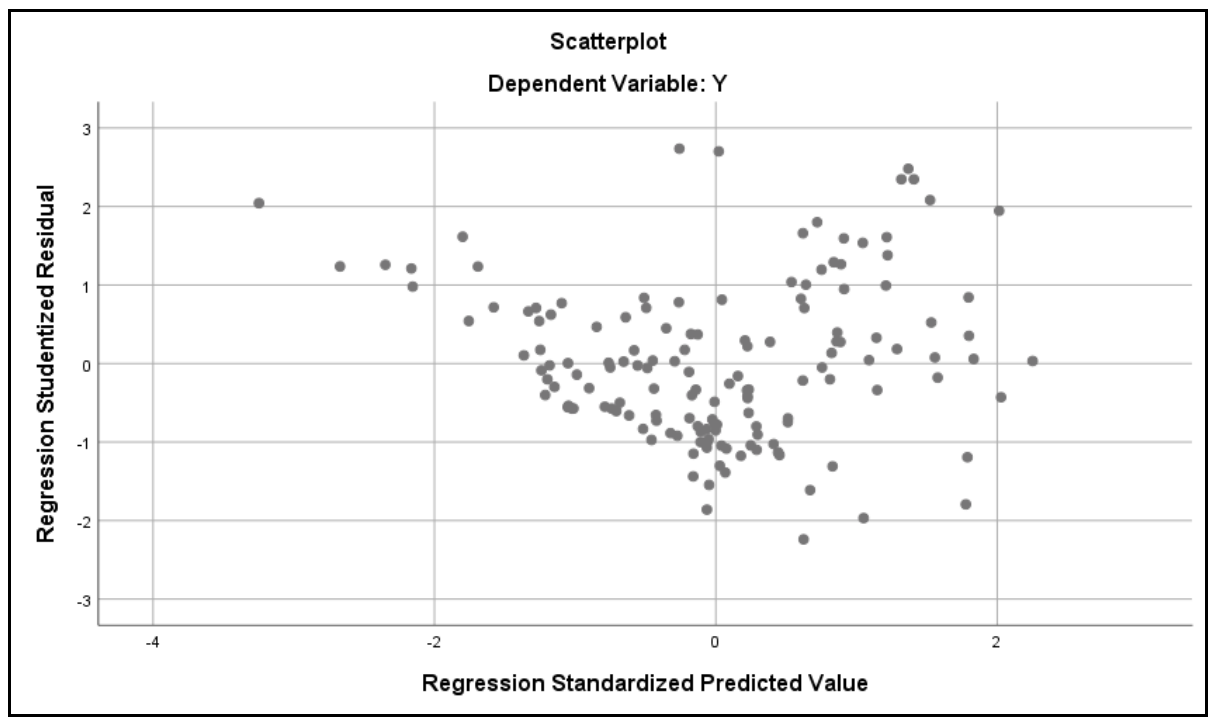

\section{Gambar 2. Uji Heteroskedastisitas dengan Scatterplot}

Berdasarkan gambar 2 menunjukkan bahwa data sampel tersebar secara acak dan tidak membentuk pola tertentu. Data tersebar baik berada diatas maupun dibawah angka 0 pada sumbu Y. Hal ini menunjukkan bahwa tidak terjadi heteroskedastisitas pada model regresi, sehingga model regresi layak dipakai.

\section{Uji Determinan}

Selanjutnya hasil uji determinan dapat disajikan pada Tabel 4.

Tabel 4. Uji Determinan

\begin{tabular}{ccccc}
\hline Model & $\mathrm{R}$ & $\begin{array}{c}\mathrm{R} \\
\text { square }\end{array}$ & $\begin{array}{c}\text { Adjusted R } \\
\text { Square }\end{array}$ & $\begin{array}{c}\text { Std. Error Of } \\
\text { Estimate }\end{array}$ \\
\hline 1 & $0,701^{\mathrm{a}}$ & 0,491 & 0,477 & 0,84294 \\
\hline
\end{tabular}

Sumber : Data Bursa Efek Indonesia diolah (2020)

Berdasarkan Tabel 4 diperoleh nilai $\mathrm{R}^{2}$ 0,477 yang berarti variabel kepemilikan institusional, dewan komisaris independen, profitabilitas, dan likuiditas dapat menerangkan 
variabilitas sebesar $47,7 \%$ terhadap nilai perusahaan. Sementara sisanya $52,5 \%$ diterangkan oleh faktor lain yang tidak terdapat dalam model penelitian ini.

\section{Pembahasan}

Hasil pengujian hipotesis disajikan pada Tabel 6, untuk menjawab semua hipotesis yang diajukan dalam penelitian ini.

Tabel 6. Regresi Linear Berganda

\begin{tabular}{|c|c|c|c|c|c|}
\hline & $\begin{array}{l}\text { Unstar } \\
\text { Coef }\end{array}$ & $\begin{array}{l}\text { rdized } \\
\text { ients } \\
\text { Std }\end{array}$ & $\begin{array}{l}\text { Standardized } \\
\text { Coefficients }\end{array}$ & & \\
\hline Model & $\mathrm{B}$ & Error & Beta & $\mathrm{t}$ & Sig \\
\hline Constanta & 0,075 & 0,715 & & 0,105 & 0,916 \\
\hline Kepemilikan Institusional & 1,15 & 0,350 & 0,201 & 3,288 & 0,001 \\
\hline $\begin{array}{c}\text { Dewan Komisaris } \\
\text { Independen }\end{array}$ & $-0,229$ & 0,680 & $-0,021$ & $-0,337$ & 0,736 \\
\hline Profitabilitas & 11,829 & 1,053 & 0,721 & 11,231 & 0,000 \\
\hline Likuiditas & 0,204 & 0,164 & 0,080 & 1,244 & 0,216 \\
\hline
\end{tabular}

Dependent variable: Nilai Perusahaan (Tobins Q)

Sumber : Data Bursa Efek Indonesia diolah (2020)

\section{Pengaruh Kepemilikan Institusional terhadap Nilai Perusahaan}

Hipotesis 1 menyatakan kepemilikan institusional berpengaruh positif signifikan terhadap nilai perusahaan. Hasil pengujian menunjukkan kepemilikan institusional berpengaruh positif terhadap nilai perusahaan dengan menghasilkan nilai koefisien sebesar 1,150 dan nilai signifikan 0,001 $(<0,05)$. Hasil ini mendukung hipotesis dengan demikian dapat dinyatakan hipotesis 1 diterima. Hasil penelitian sejalan dengan teori agensi yang menyatakan kepemilikan institusional ini akan memberikan pengaruh pengawasan yang sangat besar kepada manajemen (Michael \& H Meckling William, 1976). Hasil penelitian ini mendukung penelitian yang dilakukan oleh Damayanti \& Suartana, (2014), Sienatra et al., (2015) dan Julianti, (2015) yang menyatakan kepemilikan institusional memberikan dampak positif pada nilai perusahaan. Hasil penelitian ini tidak sejalan dengan penelitian yang dilakukan oleh Warapsari \& Suaryana, (2016) yang menyatakan bahwa kepemilikan institusional tidak berpengaruh terhadap nilai perusahaan.

Dengan adanya pengawasan dari investor akan mendorong manajemen untuk meningkatkan kinerja perusahaan yang lebih baik serta dapat mencegah terjadinya 
kecurangan yang dilakukan oleh manager. Investor akan melihat resiko terjadinya kecurangan yang dimiliki perusahaan akan rendah sehingga menimbulkan kepercayaan yang tinggi pada manajemen perusahaan. Tentunya hal ini akan berdampak para investor mau menanamkan modalnya pada perusahaan tersebut yang akan berdampak pada meningkatnya nilai perusahaan. Hasil penelitian ini menunjukkan bahwa selama periode pengamatan jumlah rata-rata kepemilikan institusional sebesar 68,74\%. Hal ini memberikan bukti bahwa terdapat kecenderungan kepemilikan saham yang lebih dominan dimiliki investor institusional sehingga hal tersebut menjadi insentif bagi pemegang saham institusional untuk lebih banyak memonitoring manajemen perusahaan.

\section{Pengaruh Dewan Komisaris Independen terhadap Nilai Perusahaan}

Hipotesis 2 menyatakan bahwa dewan komisaris independen berpengaruh positif signifikan terhadap nilai perusahaan. Hasil pengujian menunjukkan pengaruh dewan komisaris independen terhadap nilai perusahaan menghasilkan nilai koefisien sebesar 0,229 dengan nilai signifikan 0,736(>0,05). Hasil ini berarti dewan komisaris independen memiliki pengaruh negatif yang tidak signifikan terhadap nilai perusahaan. Maka berdasarkan hasil uji tidak mendukung hipotesis atau dapat dinyatakan hipotesis 2 ditolak.

Hasil penelitian ini tidak sejalan dengan teori agensi yang menyatakan bahwa fungsi pengendalian yang dilakukan oleh dewan komisaris independen dapat meningkatkan nilai perusahaan. Hasil penelitian ini juga tidak mendukung penelitian terdahulu oleh Siallagan \& Machfoedz, (2006), Tambunan et al., (2017), dan Utomo et al., (2018) yang menyimpulkan semakin tinggi dewan komisaris independen semakin dapat meningkatkan nilai perusahaan. Penelitian ini lebih sejalan dengan penelitian yang dilakukan oleh Wedayanthi \& Darmayanti, (2016) yang menemukan terdapat pengaruh negatif dan tidak signifikan dari dewan komisaris independen terhadap nilai perusahaan.

Secara ideal fungsi pengendalian yang dilakukan oleh dewan komisaris independen mewakili mekanisme internal utama adalah untuk mengontrol perilaku oportunistic manajemen sehingga dapat membantu menyelerasakan kepentingan pemegang saham dari manajer. Namun dari hasil penelitian ini dapat dimaknai peran kontrol dewan komisaris independen belum maksimal terhadap upaya mendorong manajemen dalam meningkatkan nilai perusahaan. Peningkatan peran kontrol dewan komisaris independen dapat ditingkatkan dengan menambah frekuensi volume rapat dewan komisaris dengan manajer 
untuk menghasilkan keputusan-keputusan manajerial yang berdampak pada meningkatkan nilai perusahaan.

\section{Pengaruh profitabilitas terhadap Nilai Perusahaan}

Hipotesis 3 menyatakan profitabilitas berpengaruh positif signifikan terhadap nilai perusahaan. Hasil pengujian menunjukkan pengaruh profitabilitas terhadap nilai perusahaan menghasilkan nilai koefisien 11,829 dengan nilai signifikan $0,000(<0,05)$. Hal ini bermakna profitabilitas memiliki pengaruh positif yang signifikan terhadap nilai perusahaan. Dengan demikian hasil ini mendukung hipotesis atau dapat dinyatakan hipotesis 3 diterima. Yang artinya semakin tinggi profitabilitas maka semakin meningkat juga nilai perusahaan.

Hasil penelitian ini mendukung teori signaling, yang menjelaskan profitabilitas menjadi sinyal dari manajemen yang menggambarkan prospek perusahaan yang positif. Maka ketika investor menerima informasi yang baik tentang perusahaan akan mendorong investor bereaksi membeli saham perusahaan tersebut sehingga berdampak meningkatnya nilai perusahaan (Wulandari, 2013). Hasil penelitian sejalan dengan penelitian Nurhayati, (2013) dan Dewi et al., (2014) yang menyatakan bahwa profitabilitas mempengaruhi secara positif nilai perusahaan. Penelitian ini juga sebagai bukti membantah hasil penelitian Herawati, (2013) yang menyatakan bahwa profitabilitas tidak mempengaruhi nilai perusahaan.

Semakin besar profit yang didapatkan perusahaan maka menunjukkan keuntungan yang semakin meningkat. Investor akan tertarik untuk menanamkan modalnya karena melihat perusahaan memiliki nilai proftabilitas yang tinggi. Semakin banyak investor yang menanamkan modalnya akan berdampak pada peningkatan harga saham yang membuat nilai perusahaan akan meningkat.

\section{Pengaruh Likuiditas terhadap Nilai Perusahaan}

Hipotesis 4 menyatakan bahwa likuiditas berpengaruh positif signifikan terhadap nilai perusahaan. Hasil output menunjukkan penaruh likuiditas pada nilai perusahaan menghasilkan nilai koefisien sebesar 0,204 dengan nilai signifikan 0,216 (>0,05). Artinya likuiditas tidak memiliki pengaruh yang signifikan pada nilai perusahaan, maka hasil ini menolak hipotesis atau dapat dinyatakan hipotesis 4 tidak diterima. 
Penelitian ini tidak mendukung dari teori signaling yang menyatakan dengan tingkat likuiditas yang tinggi, maka pasar akan menaruh kepercayaan terhadap perusahaan karena dapat menjaga tingkat likuiditasnya sehingga mendapatkan valuasi yang tinggi dari pasar. Hasil penelitian ini juga tidak mendukung penelitian Nurhayati, (2013), Anzlina \& Rustam, (2013), dan Rompas, (2016) yang menyatakan likuiditas berdampak positif terhadap nilai perusahaan. Hasil penelitian lebih sejalan dengan penelitian Alfredo Mahendra Dj et al., (2012) yang menyatakan bahwa likuiditas berpengaruh positif namun tidak signifikan terhadap nilai perusahaan.

Hasil penelitian Ini mengindikasikan semakin tinggi atau rendahnya tingkat likuiditas tidak akan mempengaruhi nilai perusahaan, kondisi ini dapat dijelaskan bahwa dalam pasar modal indonesia pergerakan harga saham dan penciptaan nilai tambah perusahaan lebih disebabkan oleh faktor psikologis pasar (Alfredo Mahendra Dj et al., 2012). Dari hasil ini dapat dimaknai bahwa investor tidak terlalu memfokuskan pengamatannya terhadap nilai likuiditas suatu perusahaan dalam pengambilan keputusannya berinvestasi tetapi lebih memperhatikan faktor lainnya.

\section{KESIMPULAN DAN SARAN}

Penelitian ini menguji efek mekanisme good corporate governance dan kinerja keuangan terhadap nilai perusahaan. Berdasarkan hasil pengujian yang dilakukan, maka dapat disimpulkan bahwa kepemilikan institusional memberikan berpengaruh yang positif terhadap nilai perusahaan atau semakain meningkat kepemilikan institusional maka semakin meningkat nilai perusahaan. Dewan komisaris Independen tidak memberikan dampak apapun pada nilai perusahaan. Profitabilitas berpengaruh positif terhadap nilai perusahaan atau semakin meningkat profitabilitas semakin meningkat nilai perusahaan. Sementara tingkat likuiditas tidak memberikan dampak apapun terhadap nilai perusahaan.

Perusahaan dapat meningkatkan nilainya melalui peningkatan monitoring oleh pemegang saham institusional atau semakin besar kepemilikan institusional semakin memiliki insentif yang kuat mendorong manajemen bertindak selaras dengan tujuan pemegang saham. Hasil penelitian juga memberikan implikasi bahwa peningkatan profitabilitas yang berkelanjutan akan dapat meningkatkan kesejahteraan para pemilik perusahaan. Selain itu untuk meningkatkan peran monitoring dewan komisaris independen dapat dilakukan dengan meningkatkan frekuensi rapat bersama manajer dan berfokus pada pemecahan masalah-masalah manajerial serta pengambilan keputusan yang dapat 
e-ISSN 2627-7872/2088-8554

berkontribusi pada kinerja dan nilai perusahaan. Sementara untuk tingkat likuiditas walaupun hasil menunjukkan tidak memiliki pengaruh pada nilai perusahaan, namun perusahaan harus tetap menjaganya pada tingkat rasio yang kuat karena dalam jangka panjang kinerja yang tinggi akan memberikan keberlanjutan dan keunggulan bagi perusahaan. 


\section{DAFTAR PUSTAKA}

Alfredo Mahendra Dj, Artini, L. G. S., \& A.A Gede Suarjaya. (2012). Pengaruh Kinerja Keuangan Terhadap Nilai Perusahaan Pada Perusahaan Manufaktur Yang Terdaftar Di Bursa Efek Indonesia. Parameter, 4(1), 130-138. https://doi.org/10.37751/parameter.v4i1.31

Anggraini, D. (2013). Pengaruh Good Corporate Governance Terhadap Nilai Perusahaan Pada Perusahaan Textile, Garment yang Terdaftar di Bursa Efek Indonesia(BEI)Periode 2009-2012. Jurnal Jurusan Akuntansi Fakultas Ekonomi Universitas Maritim Raja Ali Haji Tanjungpinang.

Anzlina, C. W., \& Rustam. (2013). Pengaruh Tingkat Likuiditas, Solvabilitas, Aktivitas, dan Profitabilitas Terhadap Nilai Perusahaan Real Estate dan Property di BEI Tahun 2006-2008. Jurnal Ekonom, 16(2), 67-75.

Azzahra, Z., \& Yuliandari, W. S. (2014). Pengaruh Mekanisme Good Corporate Governance Terhadap Nilai Perusahaan. Journal of Chemical Information and Modeling, 1(3), 1-11.

Basuki, agus tri and Prawonto, N (2017) Analisis Regresi Dalam Penelitian Ekonomi \& Bisnis, Foreign Affairs doi: 10.1017/CB09781107415324.004

Damayanti, N. P. W. P., \& Suartana, I. W. (2014). Pengaruh Kepemilikan Manajerial Dan Kepemilikan Institusional Pada Nilai Perusahaan. E-Jurnal Akuntansi, 9(3), 575-590.

Dewi, L. C., \& Nugrahanti, Y. W. (2014). Pengaruh Struktur Kepemilikan Dan Dewan Komisaris Independen Terhadap Nilai Perusahaan (Studi Pada Perusahaan Industri Barang Konsumsi Di BEI Tahun 2011-2013). Kinerja, 18(1).

Dewi, P. Y. S. D., Yuniarta, G. A., \& Atmadja, A. W. T. (2014). Pengaruh Struktur Modal, Pertumbuhan Perusahaan Dan Profitabilitas Terhadap Nilai Perusahaan Pada Perusahaan Lq 45 Di Bei Periode 2008-2012. E- Journal S1 Ak Universitas Pendidikan Ganesha, 2(1), 1-10.

Fatimah, Mardani, R. M., \& Budi Wahono. (2017). Pengaruh Good Corporate Governance Terhadap Nilai Perusahaan Dengan Kinerja Keuangan Sebagai Variabel Intervening (Studi Kasus Pada Perusahaan Manufaktur Sektor Barang Konsumsi yang Terdaftar di BEI Tahun 2015-2017). E-Jurnal Riset Manajemen Prodi Manajemen, 51-69.

Ferraioli, D., Gourvès, L., Moretti, S., Pascual, F., \& Spanjaard, O. (2014). Pengaruh Return On Asset (ROA), Current Ratio (CR), Return On Equity (ROE), Debt To Equity Ratio (DER), Dan Earning Per Share (Eps) Terhadap Harga Saham Perusahaan Manufaktur Sektor Industri Barang Konsumsi Di BEI. Paradigms of Combinatorial Optimization: Problems and New Approaches: 2nd Editio, 675-706. https://doi.org/10.1002/9781119005353.ch21

Ghozali, I. (2016). Aplikasi Analisis Multivarel dengan Program IBM SPSS 23.(P.P.Harto,Ed.) (VIII).Badan PEnerbit Universitas Diponogoro

Hanafi, J., \& Breliastiti, R. (2016). Peran Mekanisme Good Corporate Governance dalam Mencegah Perusahaan Mengalami Financial Distress. Jurnal Online Insan Akuntan, $1(1), 195-220$.

Herawati, T. (2013). Pengaruh Kebijakan Dividen, Kebijakan Hutang Dan Profitabilitas Terhadap Nilai Perusahaan. Academia.Edu, 2(2), 1-18.

Indrayati, M. R. (2010). Pengaruh Karakteristik Dewan Komisaris Terhadap Tingkat Konservatisme Akuntansi. 1-66.

Jao, R., \& Pagalung, G. (2011). Terhadap Manajemen Laba Perusahaan Manufaktur Indonesia Robert Jao Gagaring Pagalung ( Universitas Hasanuddin ). 8(1), 43-54.

Julianti, D. K. (2015). Pengaruh Good Corporate Governance Terhadap Kinerja Keuangan 
Perusahaan Pada Perusahaan Manufaktur Yang Terdaftar Di Bursa Efek Indonesia Tahun 2013 - 2016. In Diponegoro Journal of Accounting (Vol. 7, Issue 4).

Kusumadilaga, R. (2010). Pengaruh Corporate Social Responsibility Terhadap Nilai Perusahaan Dengan Profitabilitas Sebagai Variabel Moderating (Studi Empiris pada Perusahaan Manufaktur yang terdaftar di Bursa Efek Indonesia) Australian Road Research (Vol. 11, Issue 2).

Laila, N. (2011). Analisis Pengaruh Good Corporate Governance terhadap Manajemen Laba. Jurnal Ekonomi Dan Bisnis, 6-16.

Lindenberg, E. B., \& Ross, S. A. (1981). Tobin's Ratio and Industrial Organization. The Journal of Business, 54(1), 1. https://doi.org/10.1086/296120

Michael, C. J., \& H Meckling William. (1976). Value Engineering and the Lean Start-Up. 2016 Value Summit: The Power of VE.

Moradi, N. S., Aldin, M. M., Heyrani, F., \& Iranmahd, M. (2012). The Effect of Corporate Governance, Corporate Financing Decision and Ownership Structure on Firm Performance: A Panel Data Approach from Tehran Stock Exchange. International Journal of Economics and Finance, 4(6), 86-93.

Nurhayati, M. (2013). Profitabilitas likuiditas dan ukuran perusahaan pengaruhnya terhadap kebijakan dividen dan nila perusahaan sektor non jasa. Jurnal Keuangan Dan Bisnis, 5(2), 144-153.

OECD. (2004). The OECD Principles of Corporate Governance. The Corporate Responsibility Code Book: Third Edition, 216, 347-416.

Prasinta, D. (2012). Pengaruh Good Corporate Governance Terhadap Kinerja Keuangan. Accounting Analysis Journal, 1(2), 1-7.

Purwaningtyas. (2011). Analisis Pengaruh Mekanisme Good Corporate Governance Terhadap Nilai Perusahaan (Studi Empiris Pada Perusahaan Manufaktur yang Terdaftar di BEI Tahun 2007-2009). Jurnal Akuntansi, 2(1), 1-22.

Putra, A. N. D. A., \& Lestari, P. V. (2016). Pengaruh Kebijakan Dividen, Likuiditas, Profitabilitas Dan Ukuran Perusahaan Terhadap Nilai Perusahaan. E-Jurnal Manajemen Universitas Udayana, 8(5).

Revina, Januarsi, Y., \& Muhtar. (2015). Mekanisme Internal Dan Eksternal Corporate Governance Dalam Memitigasi Financial Distress Pada Industri Transportasi Di Indonesia. 1-21.

Rompas, G. P. (2016). Likuiditas, Solvabilitas dan Rentabilitas Terhadap Nilai Perusahaan BUMN Yang Terdaftar Di BEI. Jurnal EMBA, 1(3), 252-262.

R.Scoot, W. (2009). Bachelor of Business Administration-Honours Program Diploma in Business Administation. 1-6.

Sarafina, S., \& Muhammad Saifi. (2016). Pengaruh Good Corporate Governance Terhadap Kinerja Keuangan Dan Efeknya Terhadap Nilai Perusahaan (Studi Pada Badan Usaha Milik Negara yang Terdaftar di Bursa Efek Indonesia Periode 2012-2014). Jurnal Administrasi Bisnis S1 Universitas Brawijaya, 33(1), 146-153.

Setiawan, T. (2009). Analisis Pengaruh Mekanisme Good Corporate Governance Terhadap Praktek Manajemen Laba Pada Perusahaan Manufaktur Yang Terdaftar Di Bursa Efek Indonesia Peri Ode 2005-2007. Jurnal Akuntansi Kontemporer, 1(2).

Siallagan, H., \& Machfoedz, M. (2006). Mekanisme Corporate Governance, Kualitas Laba dan Nilai Perusahaan. Simposium Nasional Akuntansi 9 Padang, 61, 23-26.

Sienatra, K. B., Sumiati, \& Andarwati. (2015). Struktur Kepemilikan sebagai Determinan Nilai Perusahaan. Jurnal Akuntansi Multiparadigma, 124-132.

Spence, M. (1973). Pensinyalan Pasar Kerja Michael Spence. 87(3).

Sudiani, N., \& Darmayanti, N. (2016). Pengaruh Profitabilitas, Likuiditas, Pertumbuhan, 
Dan Investment Opportunity Set Terhadap Nilai Perusahaan. None, 5(7), 245861.

Sukirni, D. (2012). Kepemilikan Manajerial, Kepemilikan Institusional, Kebijakan Deviden Dan Kebijakan Hutang Analisis Terhadap Nilai Perusahaan. Accounting Analysis Journal, 1(2). https://doi.org/10.15294/aaj.v1i2.703

Tambunan, M. C. S., Saifi, M., \& Hidayat, R. R. (2017). Pengaruh Good Corporate Governance terhadap Nilai Perusahaan (Studi pada Perusahaan Sub Sektor Food and Beverages yang Terdaftar di BEI Tahun 2012-2015). Jurnal Administrasi Bisnis (JAB), 53(1), 49-57.

Tertuis, M. A., \& Christiawan, Y. J. (2015). "Diversity of Soil Macrofauna in Sugarcane of Hip and Lip Nature: Past Finding and Future Priorities." Pak. Entomol, 28(1), 19-26.

Trisnantari, A. N. (2008). Pengaruh Corporate Governance Pada Hubungan Pergantian Chief Executive Officer Dengan Kinerja Perusahaan. Journal of Chemical Information and Modeling, 53(9), 1689-1699.

Utomo, A. T., \& Rahardjo. (2014). Pengaruh Mekanisme Good Corporate Governance terhadap Kinerja Keuangan (Studi Empiris pada Perusahaan Manufaktur yang Terdaftar di Bursa Efek Indonesia Tahun 2010-2012). 3(3), 145-152.

Utomo, M. N., Wahyudi, S., Muharam, H., \& Sianturi, J. A. T. P. (2018). Commissioner board monitoring to create firm performance through environmentally friendly management. Journal of Environmental Management and Tourism, 9(3), 659-676. https://doi.org/10.14505/jemt.9.3(27).26

Warapsari, A. A. A. U., \& Suaryana, I. G. N. A. (2016). Pengaruh Kepemilikan Manajerial Dan Institusional Terhadap Nilai Perusahaan Dengan Kebijakan Utang Sebagai Variabel Intervening. E-Jurnal Akuntansi Universitas Udayana, 16(3), 2288-2315.

Wedayanthi, K., \& Darmayanti, N. (2016). Pengaruh Economic Value Added, Komposisi Dewan Komisaris Independen Dan Return on Assets Terhadap Nilai Perusahaan. EJurnal Manajemen Universitas Udayana, 5(6), 252158.

Wijaya, L. R. P. (2010). Implikasi keputusan investasi, keputusan pendanaan dan kebijakan deviden terhadap nilai perusahaan. Fakultas Ekonomi Universitas Sebelas Maret, 1-68.

Wulandari, D. R. (2013). Pengaruh Profitabilitas, Operating Leverage, Likuiditas Terhadap Nilai Perusahaan Dengan Struktur Modal Sebagai Intervening. Accounting Analysis Journal, 2(4), 455-463.

Yunizar, R. I., \& Rahardjo, S. N. (2014). Pengaruh Mekanisme Corporate Governance Dan Ukuran Perusahaan Terhadap Kinerja Keuangan Perusahaan. Diponegoro Journal of Accounting, O(0), 175-184.

Yusra, I. (2016). Kemampuan Rasio Likuiditas dan Solvabilitas dalam Memprediksi Laba Perusahaan: Studi Empiris pada Perusahaan Telekomunikasi. Jurnal Benefita, 1(September), 15-23. 